\title{
Effects of Financial and Non-financial Performance Measures on Customers' Perceptions of Service Quality at Islamic Banks in UAE
}

\author{
Attiea A. Marie ${ }^{1}$, Mohamed E. Ibrahim ${ }^{2} \&$ Amjad D. Al Nasser ${ }^{3}$ \\ ${ }^{1}$ Department of Accounting and Finance, Faculty of Business Administration, University of Dubai, UAE \\ ${ }^{2}$ Department of Accounting and Finance, School of Business Administration, Canadian University of \\ Dubai, UAE \\ ${ }^{3}$ Department of Statistics, Faculty of Science, Yarmouk University, Irbid, Jordan \\ Correspondence: Mohamed E. Ibrahim, Department of Accounting and Finance, School of Business \\ Administration, Canadian University of Dubai, Box 117781 Dubai, UAE. Tel: 971-4-709-6268. E-mail: \\ Mibrahim@cud.ac.ae
}

Received: June 23, 2014

doi:10.5539/ijef.v6n10p201
Accepted: August 15, $2014 \quad$ Online Published: September 25, 2014

URL: http://dx.doi.org/10.5539/ijef.v6n10p201

\begin{abstract}
This paper examines the influence of financial and non-financial performance measures on perceived Islamic banks' service quality in the United Arab Emirates. External customers and internal customers of Islamic banks were considered in the study. External customers represent individuals dealing with the banks and their sample consisted of 230 customers. Internal bank customers represent banks' employees with a sample size of 174 participants from five main Islamic banks in UAE. Data were collected mainly through a questionnaire and analyzed and tested through two proposed models using structural equation modeling techniques. The results indicate strong positive relationship between service quality and banks' performance and that banks internal operations mediate the relationship for the external customers group.
\end{abstract}

Keywords: Islamic banks, financial measures, non-financial Measures, structural equation modeling, service quality, bank performance

\section{Introduction}

Performance measurement systems are necessary for every organization to evaluate its achievements (e.g., goals, satisfaction, resource utilization, etc.). With the increased level of globalization, strong competition, and technological changes, many companies have started to use a blend of financial and non-financial measures for their performance or what many writers would call balanced scorecards (e.g., Kaplan \& Norton, 1996; Raphael \& Man, 2013). As one of the tools used in the strategic process, balanced performance measures help the company assess its accomplishment of the strategic goals and objectives.

Kaplan and Norton $(1992,1996)$ indicated that the financial measures of performance are insufficient to portray a full picture of a company's performance. Managers who rely only on financial performance measures usually end up with an incomplete view of what happened. On the other hand, the use of balanced performance measures that mix financial and non-financial measures can serve as a focal point of the organization's efforts that define and communicate its priorities to different groups of stakeholders (e.g., managers, employees, investors, customers, and the public).

As the next section on literature review reveals, a combination of financial and non-financial measures has become a popular framework in different fields such as economics, strategy, finance and accounting (Porter, 1992; Handy \& MacDonald, 1994). This will provide a complete picture of banking performance from both quantitative (objective) and qualitative (subjective) perspectives. Performance measures strongly affect the behavior of managers, employees, customers, and investors (Handy \& MacDonald, 1994; Kaplan \& Norton, 1992). Although customer satisfaction is sometimes used as a proxy for service quality, the most well-known instrument to measure service quality is SERVQUAL (Parasuraman, Zeithaml, \& Berry, 1985), which has five dimensions (Reliability, Responsiveness, Assurance, Empathy, and Tangibles).

This study was carried out through two steps. The first step attempted to relate customers' satisfaction of Islamic bank services in United Arab Emirates (UAE) to non-financial measures where customers included both external 
customers and internal customers (employees). The second step studied the relationship between customer perception of service quality and Islamic banks financial performance.

The remainder of the paper is organized into the following sections. The next section describes the literature review which is followed by the research method and model development. The fourth section reports on the results of testing for reliability and validity, the structural relationships, and the regression results. The paper ends with its conclusions, implications and limitations.

\section{Literature Review}

This section reviews relevant prior studies related to the use of financial measures, non-financial measures and service quality with special emphasis on the bank sector.

\subsection{Financial Measures}

The financial framework is the oldest paradigm for performance evaluation. Its roots are in the areas of accounting, financial management, and economics. Over the years, the accounting literature, for example, has recognized the importance of cost control, profitability, and liquidity. The literature documents the idea that reducing and controlling costs help increase profits. On the other hand, increasing revenues also helps boost profits when costs are controlled.

Financial and accounting reports employ various measures for profitability. They report profit as a gross amount (difference between revenues and cost of sale or services) or as a net amount (difference between revenues and total expenses). These amounts are absolute amounts and may not be appropriate for performance evaluation. Expressing these profit amounts as a percentage of some other base amounts seemed at a point in time to be more appropriate for performance evaluation. Consequently, performance evaluation systems have seen two new profitability measures: percentage of gross profit and rate of return on investment.

However, several authors (e.g., Kaplan \& Norton, 1992; Ibrahim, 1999) indicated that although financial measures are important, they are not enough for a good performance evaluation system. The system should also incorporate non-financial measures of performance. One rational for this trend is provided by Kelly (2007). He indicated that firm value is created through different activities that promote critical success factors. These factors include innovation, quality, productivity, and customer satisfaction. Also Gu (2005) pointed out that these success factors ultimately improve future financial performance. Current summary financial measures that report financial results, such as operating income and return on investment, are unlikely to fully reflect the long-term consequences of these activities. Hence, many firms complement summary financial measures with nonfinancial measures that reflect key value-creating activities (Kaplan \& Norton, 2001). However, Ittner and Larcker (2001) indicated that there is a lack of evidence on when and how nonfinancial measures improve managerial performance.

\subsection{Non-Financial Measures}

The use of non-financial measures to manage organizations appears to be positively associated with organizational performance on average. The association is often weak, however; there is considerable variation in the experience of individual organizations. Attempts to predict which types of organizations will benefit more from nonfinancial measures than others had mixed results (e.g., Hoque \& James, 2000; Randall, 2003).

Another stream of studies focused on the role of strategic performance measurement systems such as balanced scorecards in assisting managers to develop competitive strategies. Chenhall (2005) indicated that a distinctive feature of such systems is that they are designed to present managers with financial and non-financial measures covering different attributes that translate strategy into a coherent set of performance measures. He identified three interrelated dimensions of integrative strategic performance systems. The first is the integration between strategy and operations. The second attribute is focusing on customer linkages. The third attribute is supplier orientation.

Chow and Steve (2006) investigated the relative use of financial, nonfinancial and subjective performance measures derived from subjective judgment. They used a sample of 128 manufacturing firms. Their results indicated that companies with different manufacturing strategies use different mixes of the three types of measures. In addition, the different measures have different strengths and weaknesses (e.g., encouraging risk taking versus supporting decision making).

Briggs, Claiboborne, and Cole (2006) pointed out that financial measures are generally lagging measures of performance while nonfinancial measures such as sustainability, learning and growth, and internal process improvements are leading measures of performance that offer insight about future performance. They estimated 
that investments affect gross operating income with a three-period lag but they affect nonfinancial measures without any time lag.

Banker and Mashruwala (2007) assessed whether the reporting of nonfinancial measures such as employee satisfaction and customer satisfaction is likely to be useful to managers of a retail chain and under what competitive conditions such usefulness may take place. They found that employees and customers' satisfaction help managers in predicting future profitability. In addition, they found that customers and employees' satisfactions were correlated with the store closure decisions while customers' satisfaction only was correlated with performance evaluations of store managers.

Dikolli and Sedatole (2007) presented taxonomy of empirical refinements of the leading indicators included in prior studies, all of which improve the information content of nonfinancial performance measures (NFPMs). These refinements incorporate: (1) alternative measurements of the NFPM, (2) lag differences in the leading indicator relation, (3) interactions between the NFPM and contextual variables affecting the leading indicator relation, nonlinearities in the leading indicator relation, and (5) variables that play a mediating role in the relation between the NFPM and future financial performance.

Campbell (2008) examined the sensitivity of promotion and demotion decisions of lower-level managers to financial and nonfinancial measures of performance in a major fast-food retailer in US. He found that promotion and demotion decisions were sensitive to nonfinancial performance measures related to service quality and employee retention after controlling for financial performance. He also found evidence to suggest that lower-level managers behave in a consistent way with incentives created by assigning weights of nonfinancial performance measures. These findings provide some of the early empirical evidence on the use of weighted nonfinancial metrics in compensation contracts as a mechanism for generating improvements in performance.

Brazel, Jones, and Zembelman (2009) investigate whether comparing financial data to nonfinancial measures (NFMs) can aid auditors and others in assessing fraud risk. They predict and found that fraud firms have greater differences in percent change in revenue growth and percent change in NFMs than their non -fraud competitors. These differences are positively associated with fraudulent financial reporting after controlling for variables that have been previously linked to fraud.

\subsection{Service Quality}

Much research effort and interest in service quality have been shown in the last thirty years or so (e.g., Oliver, 1980; Brown \& Swartz, 1989; Carman, 1990; Bolton \& Drew, 1991; Cronin \& Taylor, 1992; Teas, 1993; Parasuraman, Zeithaml, \& Berry, 1985, 1988, 1991, 1994; Foley, 2008, among others). This literature indicates that service quality is determined by technical aspects as well as the delivery of the service. Customers usually judge the technical quality based on their interaction with the service providers. However, quality of the service delivery is judged based on the customers' ability to access facilities, appearances, employees' behaviors, and the overall treatment presented to customers. This notion also extends to government services (Foley, 2008).

The service quality literature advocates that the main components of service quality are the five known dimensions (tangibles, reliability, responsiveness, assurance, and empathy). Tangibles refer to the physical appearance of the bank (its facilities, staff, and equipment). Reliability refers to the ability of the employees to perform the promised service dependably and accurately. Responsiveness refers to the willingness of the employees to help customers and provide prompt service. Assurance refers to the knowledge and courtesy of the employees and their ability to convey trust and confidence. Empathy refers to the level of care and individualized attention the employees provide to customers.

Lewis, Orledge and Mitchel (1994) examined attitudes towards bank services among 147 university students. They measured students' expectations and perceptions of different bank features and services (e.g., loans, overdrafts, etc.). They used mean scores of students' expectations and perceptions to identify service quality gaps. They also used regression analysis to assess whether quality scores possess the ability to predict overall satisfaction. The results indicated higher students' expectations than their perceptions.

Naser and Al-Khatib (1999) assessed the degree of customers' awareness of and satisfaction with the products and services offered by an Islamic bank in Jordan. They used a questionnaire to collect the data from 300 customers who had transactions at the bank's branches in 1998. The results indicated that a significant number of the participants were aware of the Islamic Bank's products and services. However, a small number of participants indicated that they were taking advantage of the bank's products and services.

Cui, Lewis and Park (2003) tested the SERVQUAL and SERVPERF scales and the psychometric properties of the construct service quality in the Korean banking context. They used a 22-item questionnaire measuring 
customers' expectations, perceptions, and importance. The results indicated that the SERVQUAL and weighted SERVQUAL models did not appear to be valid for use with Koreans. On the other hand, the results of testing the non-weighted SERVPERF and the weighted SERVPERF models showed good fit only when the original 21 items were reduced to five items by partial regression. Thus, the study concluded that it was appropriate to use the five-item SERVPERF and weighted SERVPERF models as overall measures of service quality in the banking sector in Korea.

Zhou (2004) studied service quality, satisfaction, and customers' behavioral intentions a convenient sample of 373 customers in China's retail banking using a Chinese translated version of the original paired 22-item performance and expectation scales of service quality (SERVQUAL).The results showed a significant link between the reliability/assurance dimension and satisfaction. This result indicates that the specific dimensions of service quality do not contribute equally to the satisfaction of Chinese bank customers. Providing reliable banking services with promised assurance seem to be the most relevant and appealing service criteria to the target markets.

Bhat (2005) studied service quality among a random sample of 800 bank customers from five banks in Northern India using SERVQUAL. The results showed that service quality of foreign banks was higher than that of Indian banks. However, all banks fell below their customers' expectations.

Lee and Hwan (2005) studied the relationships among service quality, customer satisfaction, and profitability in the Taiwanese banking industry. The study used a sample of 145 customers and 124 bank managers. The results indicated that service quality influenced customers' attitudes and satisfaction, which influenced purchase intentions. However, customer satisfaction did not influence service quality perceptions. In addition, the results indicated that customer satisfaction with bank service quality significantly influenced bank profitability but not bank market share.

Vanniarajan and Anbazhagan (2007) studied Indian retail banking using a random sample of 15 banks. For each bank, 20 customers were targeted for interviews. The final sample size was 205 customers. The results of the regression analysis indicated significant effect of the dimensions of reliability and assurance on customers' attitudes towards retail banking services. However, there were no effects for customers of cooperative banks. In addition, responsiveness and tangibles were insignificant.

Al Metawa and Ibrahim (2013) examined the effects of front-desk employees' personality traits and their gender on customers' assessment of Islamic banks' service quality in the United Arab Emirates. They used a sample of 104 front-desk employees and 454 customers. The Mini-Markers instrument was used to assess personality traits and the SERVPERF instrument to collect data on service quality for a pair-matching sample design. The results indicate that personality traits do not have their own independent effects on customers' perceptions of Islamic banks' service quality. However, employees' gender was found to have significant effects on the empathy dimension of service quality.

\section{Research Method}

\subsection{Development of the Research Models and Hypotheses}

We have developed and tested two models to measure the relationship between Islamic banks customers' satisfaction and their effects on banks performance mediated by the bank's internal operations in UAE. The first model is expressed graphically in Figure 1.

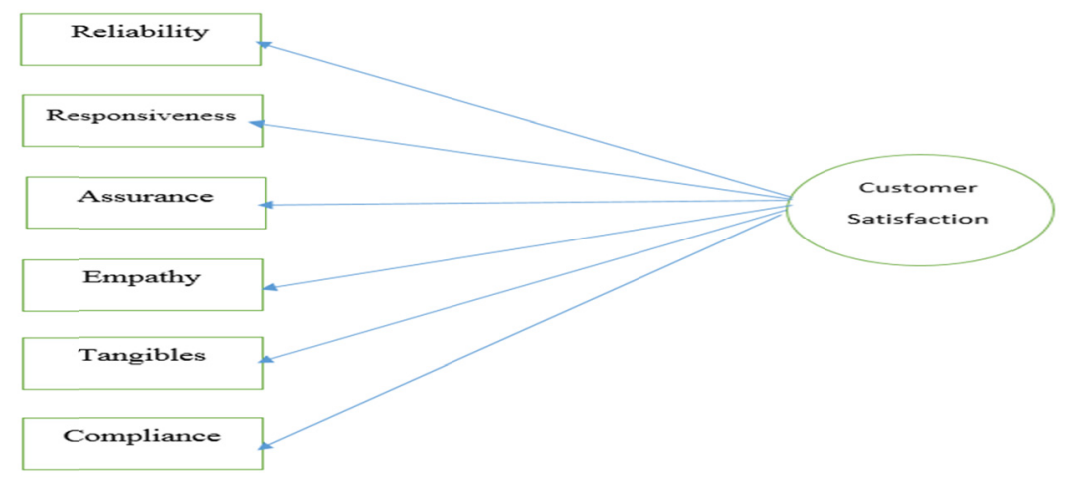

Figure 1. Non-financial measure model 
According to Othman and Owen (2001) perceived quality is considered a multidimensional construct with six dimensions: reliability, responsiveness, assurance, tangibility, empathy and compliance. The model hypothesizes that perceived quality has a positive impact on customer satisfaction. This paper uses two types of customers: bank employees (internal customers) and bank users (external customers). Accordingly, the first research hypothesis is expressed as follows:

Hypothesis 1: Service quality with its different dimensions (reliability, responsiveness, assurance, empathy, tangibles, and compliance) is positively related to nonfinancial measures.

Hypothesis 2: There is no statistical difference in the average satisfaction level of internal and external customers on Islamic bank services.

The second model (Financial measures model) depends on the results of the first model by measuring the bank performance. The financial performance of a bank (including ROA and ROE) also depends on its capital structure and solvency, management efficiency, profitability, scale, and growth-all of which are evaluated based on different financial ratios derived from financial statements as shown in Figure 2.

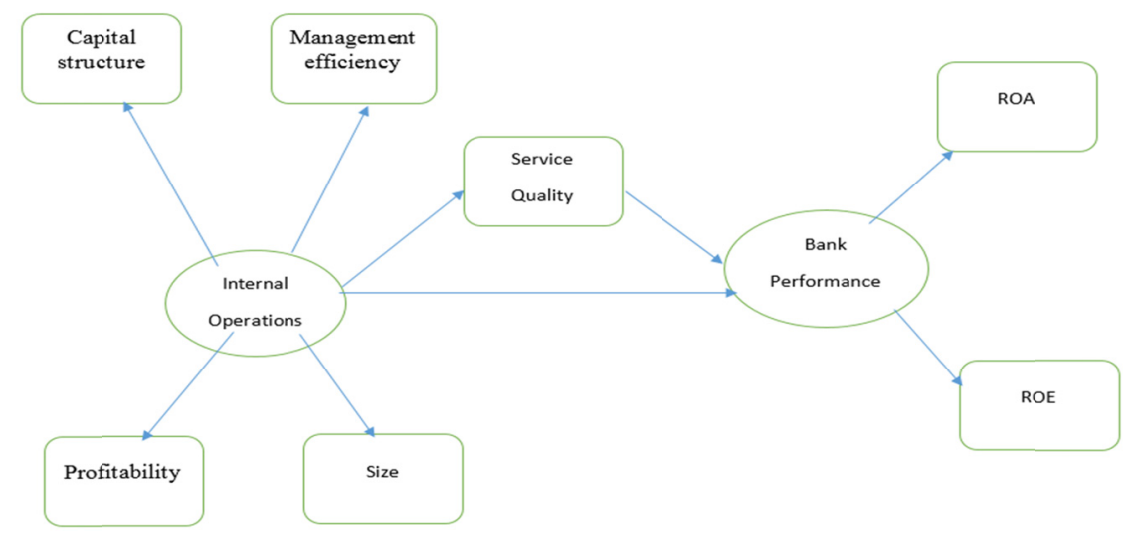

Figure 2. Financial measures model

Capital structure and solvency are represented by three ratios. They are liability ratio (liability/total assets), risk-based capital ratio (capital/risk-based assets), and the current ratio (current assets/current Liabilities). Management efficiency is also represented by three ratios. They are nonperforming loans ratio (non-performing loans/total loans), asset turnover (operating revenue/average assets), and operating revenue per employee (operating revenue/employees). Profitability is measured by return on assets (net income/average assets), return on stockholders' equity (net income/average net stockholders' equity), and net profit margin (net income/operating revenue). Size (or scale) of the bank is defined by its total assets. It is hypothesized that internal operations have a positive impact on service quality as well as the overall bank performances. Also, the service quality has positive impact on the overall bank performances. These hypothesized relationships are stated as follows:

Hypothesis 3: Internal operations (capital structure, management efficiency, profitability, and size) are positively correlated with Service quality.

Hypothesis 4: Internal operations are positively correlated with bank performances.

Hypothesis 5: Service quality is positively correlated with bank performances.

\subsection{Sampling and Data Collection Procedures}

The data for this study were selected randomly from the main five Islamic banks in UAE using two multi-item scales self-prepared questionnaires adapted from previous studies (e.g., Parasuraman, Zeithaml, \& Berry, 1988; Othman \& Owen, 2001). The questionnaires contained 32 items using a five-point Likert scale ranging from 1 (strongly disagree) to 5 (strongly agree). Potential respondents were assured that participation was entirely voluntary. Completed questionnaires were returned via a sealed envelope to a secured drop-off box for collection by the researchers only. The survey was conducted over a five-month period. The final sample size was 404 respondents (230 external customers and 174 internal customers); with overall response rate of $47 \%$. 


\subsection{Setting up the Non-Financial Model}

It is known that the customer satisfaction cannot be directly measured but can be evaluated by means of several dimensions which describe different factors. In order to formulate the non-financial model we assume the basic hypothesis that the internal and the external customers satisfaction can be obtained by reducing the dimensionality of multiple items of our tool.

In order to test the first hypothesis we adopt nonlinear principle component analysis (NLPCA). The NLPCA was performed with two components considering the ordinal scaling that used in the research questionnaires; Table.1 shows the fit indices for each subgroup: Internal customers (employees) and external Customers).

Table.1. Model summary: PVAF and VAF obtained by NLPCA

\begin{tabular}{lcc}
\hline & External Customers & Internal Customers (Employees) \\
\hline PVAF 1 $1^{\text {st }}$ component & 51.974 & 52.927 \\
PVAF 2 ${ }^{\text {nd }}$ component & 23.433 & 12.203 \\
PVAF Total & 75.408 & 65.130 \\
VAF 1 $1^{\text {st }}$ component & 4.158 & 3.705 \\
VAF 2 $2^{\text {nd }}$ component & 1.875 & .854 \\
VAF Total & 6.033 & 4.559 \\
Cronbach's $\alpha$ & .953 & .911 \\
\hline
\end{tabular}

The measure of goodness of fit in NLPCA can be obtained in two alternative ways. The first one is the percentage of total variance accounted for (PVAF total). The second alternative is the value of Cronbach's $\alpha$; where the larger the ratio is, the better is the synthesis (Manisera, 2010)

In terms of PVAF total and Cronbach's $\alpha$, external customers are slightly higher than the internal customer model. Now, in order to set up the number of components that affect the Islamic bank customer satisfaction, we used an eigenvalue greater than one criterion and the scree test (Figure 3).

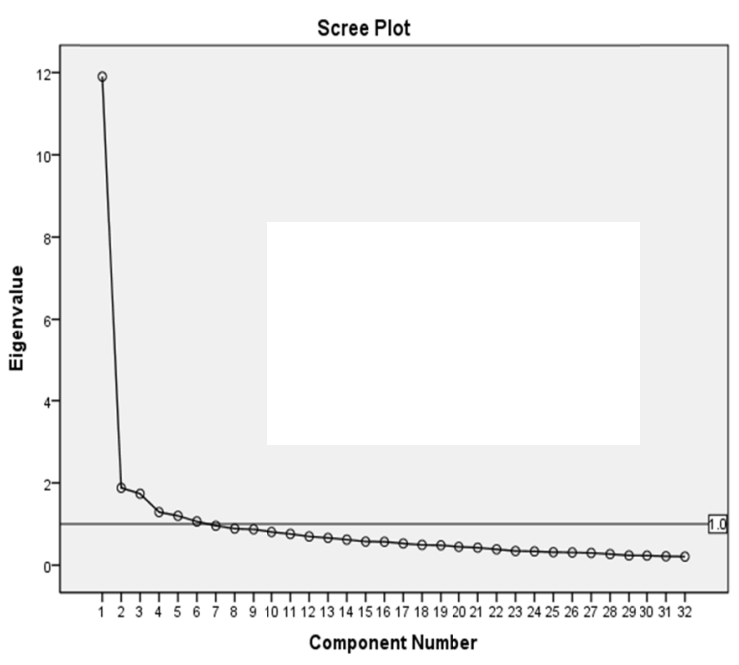

External Customers

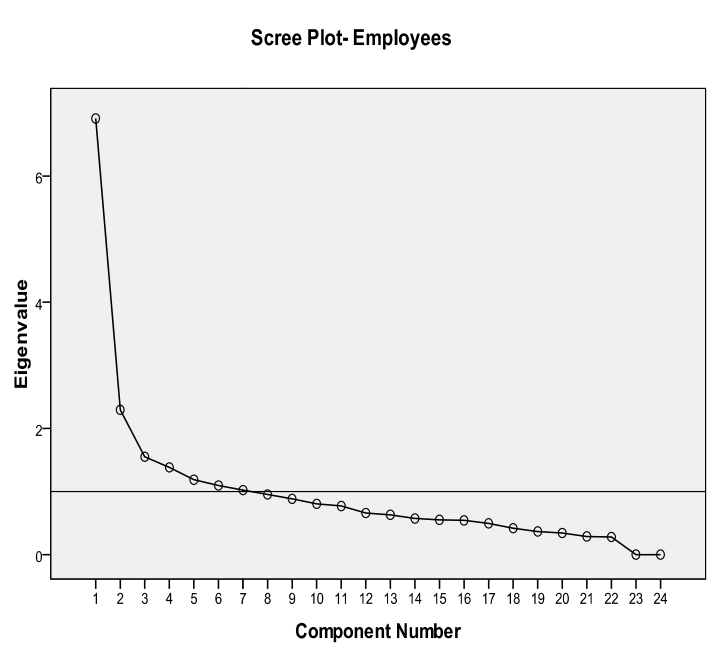

Internal Customers

Figure 3. Scree plot 


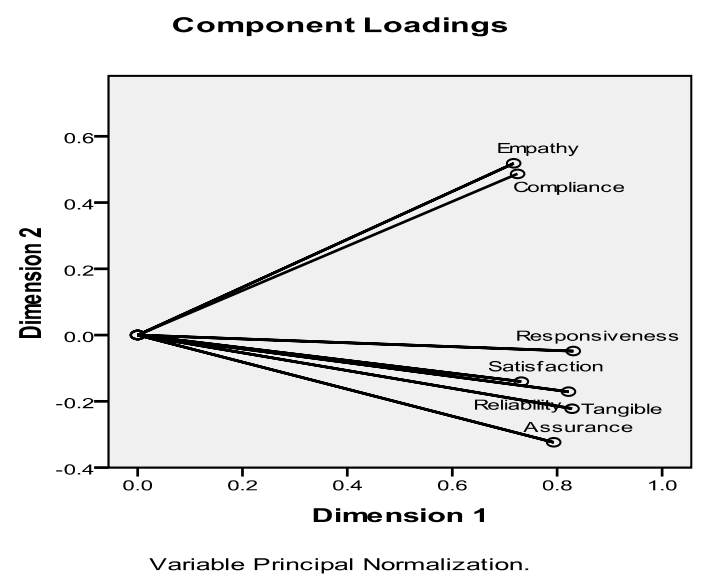

External Customers

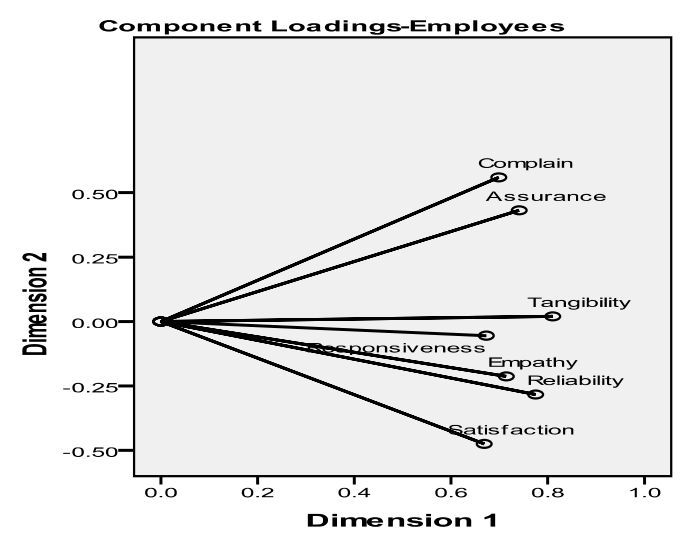

Internal Customers

Figure 4. Component loadings

\section{Test Results}

\subsection{Testing for Reliability and Validity}

Reliability is the degree to which measures yield consistent results (Peter, 1979). Validity, on the other hand, measures the accuracy of an instrument (Stewart, 2009). We used cronbach's alpha as the measure of reliability. For construct validity, we used different trials of confirmatory factor analysis (CFA). For validity testing; and based on the standardized loading and the error variance associated with each observed variable; we used three indicators: the average variance extracted (AVE) for convergent validity; the composite reliability (CR) to determine the internal consistency of a set of measures and discriminant validity (DV) which reflects the degree to which a dimension in a theoretical system differs from other dimensions in the same study (Churchil, 1979). Table 2 shows all indicators of the non-financial model.

Table 2. Reliability and validity statistics for internal and external models

\begin{tabular}{lllllllcc}
\hline $\begin{array}{l}\text { Dimension } \\
\text { Dimension }\end{array}$ & $\begin{array}{l}\text { External } \\
\text { Cronbach's Alpha }\end{array}$ & CR & AVE & DV & Cronbach's Alpha & CR & AVE & DV \\
\hline Complaints & 0.664 & 0.812 & 0.465 & 0.682 & 0.785 & 0.833 & 0.559 & 0.748 \\
Assurance & 0.722 & 0.843 & 0.576 & 0.759 & 0.681 & 0.838 & 0.495 & 0.703 \\
Reliability & 0.744 & 0.891 & 0.537 & 0.733 & 0.710 & 0.891 & 0.540 & 0.735 \\
Tangible & 0.680 & 0.820 & 0.547 & 0.740 & 0.666 & 0.806 & 0.526 & 0.725 \\
Empathy & 0.745 & 0.792 & 0.489 & 0.699 & 0.807 & 0.812 & 0.564 & 0.751 \\
Response & 0.825 & 0.827 & 0.545 & 0.738 & 0.615 & 0.794 & 0.466 & 0.682 \\
Satisfaction & 0.749 & 0.887 & 0.663 & 0.814 & 0.703 & 0.875 & 0.637 & 0.798 \\
\hline
\end{tabular}

The results in Table 2 showed that the CR greater than 0.7 the recommended threshold requirements for all dimensions; however, AVE values are acceptable if they exceeds 0.5 (Graver \& Mentzer, 1999) therefore; two dimensions (Complaints and Empathy) will not considered in the external customers model. In addition, one dimension (responsiveness) will not be considered in the internal customer model. Also, it is worth to compare between the DV and the correlation values given in Table 4 and Table 5, it is very clear that DV values are larger than the correlation values within each dimension which indicate an evidence of discriminant validity (Fornell \& Larcker, 1981). Moreover, the overall Cronbach's Alpha for both groups (External and Internal) are high and equal to .940 and 0.896 ; respectively; indicating a very good reliability of scale measurement. Furthermore, the items are regrouped into the optimal dimensions showing that customer satisfaction (Internal or External) with service in Islamic Banks in UAE is a multidimensional construct that allows explaining of $59.6 \%$ of variance (External satisfaction) and $66.9 \%$ of variance (Internal satisfaction).

Pairwise correlation was also used to test the convergent validity (Anderson et al., 1987). If the lowest correlation of a particular dimension is significant at $\mathrm{p}<0.01$, convergent validity exists (Koufteros, 
Vonderembse, \& Doll, 1998). In Table 3 and Table 4, the results show that the correlations values for each dimension are greater than 0.60 and 0.39 for external and internal models, respectively, and are significant at the 0.01 level. These results indicate initial evidence of good convergent validity.

Table 3. Pairwise correlations and violations of discriminant validity for external customer's model

\begin{tabular}{lcccc}
\hline & Assurance & Reliability & Tangible & Response \\
\hline Assurance & 1 & & & \\
Reliability & $.720^{* *}$ & 1 & & \\
Tangible & $.719^{* *}$ & $.712^{* *}$ & 1 & \\
Response & $.745^{* *}$ & $.741^{* *}$ & $.657^{* *}$ & 1 \\
\hline
\end{tabular}

Note. $* *$ Coefficient is significant at the 0.01 level.

Table 4. Pairwise correlations and violations of discriminant validity for internal customer's model

\begin{tabular}{llllll}
\hline & Complaints & Assurance & Reliability & Tangible & Empathy \\
\hline Complaints & 1 & & & & \\
Assurance & $.604^{* *}$ & 1 & & \\
Reliability & $.391^{* *}$ & $.453^{* *}$ & 1 & \\
Tangible & $.446^{* *}$ & $.492^{* *}$ & $.499^{* *}$ & 1 & \\
Empathy & $.435^{* *}$ & $.455^{* *}$ & $.520^{* *}$ & $.543^{* *}$ & 1 \\
\hline
\end{tabular}

Note. ** Coefficient is significant at the 0.01 level.

\subsection{Testing for the Non-Financial Structural Relationships}

The research proposed models were tested using a linear structural equation modeling (SEM) with latent variables; which is well suited to highly complex predictive models (Jöreskog, 1973). SEM has several strengths that made it appropriate for this study, including its ability to handle both reflective and formative constructs. SEM analyses were performed using a covariance matrix as input to the Analysis of Moment Structure software package (Arbuckle \& Wothke, 2003), using maximum likelihood estimation. The missing data were replaced by using the expectation maximization (EM) approach prior to analysis. For the evaluating of the model, residual means squared error (RMSEA), standardized root mean square residual (RMR), normed fit index (NFI), incremental fit index (IFI), comparative fit index (CFI) and goodness of fit index (GFI) values were taken into consideration. Noting that; a fit index value more than 0.90 and means squared error less than 0.08 would indicate a close fit of the model.

Table 5. Regression coefficients of overall service quality

\begin{tabular}{|c|c|c|c|c|c|c|c|c|c|c|}
\hline \multirow[b]{2}{*}{ Dimension } & \multicolumn{5}{|c|}{ External } & \multicolumn{5}{|c|}{ Internal } \\
\hline & Estimates & $\begin{array}{c}\text { Standardized } \\
\text { Estimates }\end{array}$ & S.E & $\begin{array}{c}\text { Critical } \\
\text { Ratio }\end{array}$ & p-value & Estimates & $\begin{array}{c}\text { Standardized } \\
\text { Coefficient }\end{array}$ & S.E & $\begin{array}{c}\text { Critical } \\
\text { Ratio }\end{array}$ & p-value \\
\hline Complaints & & & $* * * *$ & & & 0.581 & 0.967 & 0.202 & 2.870 & 0.004 \\
\hline Assurance & 0.790 & 0.868 & 0.068 & 11.629 & 0.000 & 1.457 & 0.727 & 0.350 & 4.164 & 0.000 \\
\hline Reliability & 0.790 & 0.982 & 0.072 & 10.962 & 0.000 & 1.374 & 0.656 & 0.318 & 4.321 & 0.000 \\
\hline Tangible & 0.836 & 0.909 & 0.067 & 12.439 & 0.000 & 1.321 & 0.764 & 0.328 & 4.025 & 0.000 \\
\hline Response & 1.266 & 0.946 & 0.109 & 11.629 & 0.000 & & & $* * * *$ & & \\
\hline Empathy & & & $* * * *$ & & & .779 & .864 & .206 & 3.778 & 0.000 \\
\hline GFI & & & 0.915 & & & & & 0.931 & & \\
\hline NFI & & & 0.904 & & & & & 0.825 & & \\
\hline IFI & & & 0.936 & & & & & 0.902 & & \\
\hline CFI & & & 0.935 & & & & & 0.895 & & \\
\hline RMR & & & 0.044 & & & & & 0.047 & & \\
\hline RMSEA & & & 0.067 & & & & & 0.080 & & \\
\hline Chi/df & & & 2.283 & & & & & 2.101 & & \\
\hline
\end{tabular}

Note. $* * * *$ The dimension is retired from the model. 
The chi-square statistic for both models is significant with $\mathrm{p}$ value less than 0.05 and the ratio $\chi^{2} / \mathrm{df}$ (see Table 5) drops well below the maximum value of 3 recommended by Kline (1998), indicating a good model fit. Moreover, it is worth to say that the fit indices given in Table 4 provide strong support for the external customer's model and most of these indices met the criterion but not the NFI (0.825) for the internal customer's model.

The estimated standardized regression coefficients are given in Table 5. These results are the answers of the first hypothesis, which indicate there is a positive relationship between customer satisfaction and all other dimensions for both models. Based on the standardized coefficients values it could be noted that the most important factor that effects on the external customer's satisfactions is the reliability $(\beta=0.982)$ then responsiveness $(\beta=0.946)$; tangibility $(\beta=0.909)$ and the least important factor is the assurance $(\beta=0.868)$. However, we observed different inference about the internal satisfaction preferences, where the complaint $(\beta=0.967)$ is the most factor effects on the internal customer's satisfaction, then empathy $(\beta=0.864)$, tangibility $(\beta=0.764)$, assurance $(\beta=$ $0.727)$ and the least important is the reliability $(\beta=0.656)$.

Table 6. Comparisons between internal and external satisfaction levels

\begin{tabular}{|c|c|c|c|c|c|}
\hline Dimension & Customers & Mean & St. Dev & Critical Ratio & Significance level \\
\hline \multirow{2}{*}{ Complaints } & External & 3.5758 & .83919 & \multirow{2}{*}{-3.862} & \multirow{2}{*}{.000} \\
\hline & Internal & 3.8678 & .62120 & & \\
\hline \multirow{2}{*}{ Assurance } & External & 3.4766 & 1.01872 & \multirow{2}{*}{-5.269} & \multirow{2}{*}{.000} \\
\hline & Internal & 3.9287 & .56811 & & \\
\hline \multirow{2}{*}{ Reliability } & External & 3.4270 & .86689 & \multirow{2}{*}{-4.467} & \multirow{2}{*}{.000} \\
\hline & Internal & 3.7713 & .61191 & & \\
\hline \multirow{2}{*}{ Tangible } & External & 3.5417 & .95589 & \multirow{2}{*}{-4.185} & \multirow{2}{*}{.000} \\
\hline & Internal & 3.9042 & .72111 & & \\
\hline \multirow{2}{*}{ Empathy } & External & 3.4690 & .92620 & \multirow{2}{*}{-4.142} & \multirow{2}{*}{.000} \\
\hline & Internal & 3.8123 & .66898 & & \\
\hline \multirow{2}{*}{ Response } & External & 3.4221 & 1.34180 & \multirow{2}{*}{-5.550} & \multirow{2}{*}{.000} \\
\hline & Internal & 4.0575 & .79773 & & \\
\hline \multirow{2}{*}{ Overall Satisfaction } & External & 3.4078 & .93717 & \multirow{2}{*}{-4.059} & \multirow{2}{*}{.000} \\
\hline & Internal & 3.7425 & .63603 & & \\
\hline
\end{tabular}

We also used the independent t test to compare between the customers (external and internal) satisfaction level (Table 6). The results indicated that there is a statistical difference between both groups, where the internal customers (Employees) are satisfied more than the external customers; in the bank service quality. Similar results also obtained in all non-financial dimension comparisons.

\subsection{Relationship between Customer Perceptions and Financial Performance}

We analysed the financial hypothesized model using structural equation modelling. The fit of the measurement model was acceptable, despite a significant chi-square $\left(\chi^{2}(8)=675.371, \mathrm{P}<0.001\right.$; $\mathrm{RMR}=0.045$; GFI $=0.953$; $\mathrm{NFI}=0.902 ; \mathrm{CFI}=0.909$ and $\mathrm{RMSEA}=0.048)$ for the external customer model and square $\left(\chi^{2}(8)=405.334, \mathrm{P}\right.$ $<0.001 ; \mathrm{RMR}=0.051 ; \mathrm{GFI}=0.911 ; \mathrm{NFI}=0.890 ; \mathrm{CFI}=0.883$ and $\mathrm{RMSEA}=0.078)$ for the internal customer's model.

Tables 7 and 8 show the results of hypotheses 3, 4 and 5. It could be noted that the significant financial measures model differs between the internal and the external customers in terms of the service quality impact. While this dimension has a significant values and it has a positive impact on performances and on internal operations for the external customers, it has no significant impact in the case of internal customer models. In addition, there are similarities in terms of significant relations within all other measures, and it worth to say the standardized effects in the external customers are leading the same values in the internal customers model. The significant structural models for both groups are given in Figure 5. 
Table 7. Regression coefficients of financial measures for external customers

\begin{tabular}{llccccc}
\hline & & Estimate & Standardized Estimates & S.E. & C.R. & P \\
\hline Service Quality & Operations & .000 & .177 & .000 & 4.474 & .000 \\
Performance & Service Quality & .002 & .286 & .001 & 4.662 & .000 \\
Performance & Operations & .000 & .532 & .000 & 11.817 & .000 \\
Capital structure & Operations & .097 & 1.039 & .005 & 20.301 & .000 \\
Management efficiency & Operations & .013 & .606 & .004 & 3.044 & .000 \\
Profitability & Operations & .011 & .926 & .002 & 5.713 & .000 \\
Size & Operations & .057 & .920 & .002 & 29.990 & .000 \\
ROA & Performance & .001 & .177 & .000 & 7.396 & .000 \\
ROE & Performance & 0.041 & .286 & .006 & 6.833 & .000 \\
\hline
\end{tabular}

Table 8. Regression coefficients of financial measures for internal customers

\begin{tabular}{llccccc}
\hline & & Estimate & Standardized Estimate & S. E & C.R & P \\
\hline Service Quality & Operations & .000 & .001 & .000 & .521 & .603 \\
Performance & Service Quality & .000 & .038 & .000 & .480 & .631 \\
Performance & Operations & .000 & .045 & .000 & 7.872 & .000 \\
Capital structure & Operations & 93.620 & 1.018 & 2.700 & 34.668 & .000 \\
Management efficiency & Operations & .011 & .569 & .001 & 12.931 & .000 \\
Profitability & Operations & .012 & .960 & .000 & 67.403 & .000 \\
Size & Operations & .060 & .968 & .001 & 83.514 & .000 \\
ROA & Performance & .102 & .787 & .003 & 35.212 & .000 \\
ROE & Performance & 8.411 & .632 & .730 & 11.520 & .000 \\
\hline
\end{tabular}
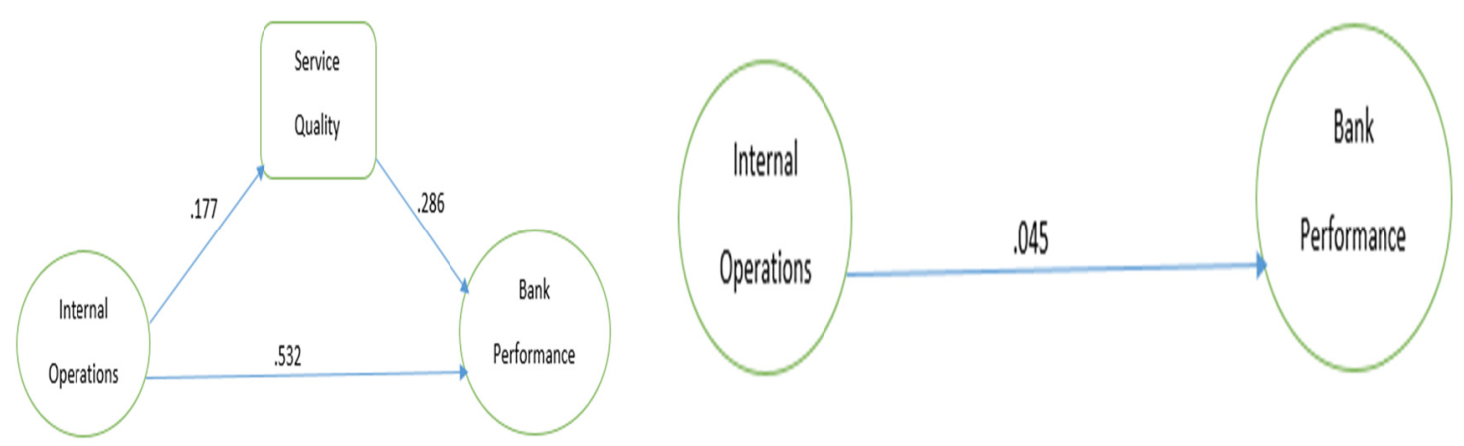

Figure 5. Significant structural financial model

\section{Concluding Remarks}

This study provides an attempt to test empirically the service quality in Islamic banks using two models that are based on financial and non-financial measures. The non-financial model is similar to others models that deal with the effect of service quality on customer satisfactions in the context of Islamic banks. However, the financial model is used as an extension to the first model based on its results to study the effects of the internal operations using bank performances measures such as ROA and ROE, mediated by the service quality; in a cross-culture context of the UAE. We used multi group analysis along with the structural equation modeling techniques to test five hypotheses under the two models. Therefore, this paper helps to bridge the gap between the western theories and the none-western practices.

The results indicate strong positive relationship between service quality and banks' performance and that banks internal operations mediate the relationship for the external customers group. However, one should be caution when interpreting these results as we did not compare the results of Islamic banks with commercial banks. This could be one of the future research avenue to extend this type research.

\section{Acknowledgements}

We would like to thank participants of the research seminar as well as the journal reviewers for their constructive 
comments on an earlier version of this paper.

\section{References}

Al-Mutawa, S. A., \& Ibrahim, M. E. (2013). Effects of Gender and Personality Traits of Front-Desk Employees on Customers' Assessment of Service Quality: Evidence from Islamic Banks in the UAE. International Journal of Business and Management, 8(15), 1-19. http://dx.doi.org/10.5539/ijbm.v8n15p1

Anderson, J. C. (1987). An approach for confirmatory measurement and structural equation modeling of organizational properties. Management Science, 33(4), 525-541. http://dx.doi.org/10.1287/mnsc.33.4.525

Arbuckle, J. L., \& Wothke, W. (1999). Amos 4.0 User's Guide, Chicago. IL: Small Waters Corporation.

Banker, R. D., \& Mashruwala, R. (2007). The Moderating Role of Competition in the Relationship between Nonfinancial Measures and Future Financial Performance. Contemporary Accounting Research, 24(3), 763-793. http://dx.doi.org/10.1506/car.24.3.4

Bhat, M. A. (2005). Correlates of service quality in banks: An empirical investigation. Journal of Services Research, 5(1), 77-99.

Brazel, J. F., Jones, K. L., \& Zimbelman, M. (2009). Using nonfinancial measures to assess fraud risk. Journal of Accounting Research, 47(5), 1135-1166. http://dx.doi.org/10.1111/j.1475-679X.2009.00349.x

Briggs, J., Claiboborne, M. C., \& Cole, E. (2006). Total optimal performance scores: a practical guide for integrating financial and nonfinancial measures in performance evaluation. Management Accounting Quarterly, 8(1),11-23.

Campbell, D. (2008). Nonfinancial performance measures and promotion-based incentives. Journal of Accounting Research, 46(2), 297-332. http://dx.doi.org/10.1111/j.1475-679X.2008.00275.x

Chenhall, R. (2005). Integrative strategic performance measurement systems, strategic alignment of manufacturing, learning and strategic outcomes: An exploratory study. Accounting, Organizations and Society, 30(5), 395-422. http://dx.doi.org/10.1016/j.aos.2004.08.001

Chow, C., \& Steve, W. (2006). The Use and Usefulness of Nonfinancial Performance Measures. Management Accounting Quarterly, 7(3),1-8.

Churchill, G. A. Jr. (1979). A Paradigm for developing better measures of marketing constructs. Journal of Marketing Research, 16, 64-73. http://dx.doi.org/10.2307/3150876

Cronin, J. J., \& Taylor, S. A. (1992). Measuring service quality: A re-examination and extension. Journal of Marketing, 56(1), 55-68. http://dx.doi.org/10.2307/1252296

Cui, C. C., Lewis, B. R., \& Park, W. (2003). Service quality measurement in the banking sector in South Korea. International Journal of Bank Marketing, 11(4), 191-201. http://dx.doi.org/10.1108/02652320310479187

Dikolli, S. S., \& Sedatole, K. L. (2007). Improvements in the Information Content of Nonfinancial Forward-Looking Performance Measures: A Taxonomy and Empirical Application. Journal of Management Accounting Research, 19, 71-104. http://dx.doi.org/10.2308/jmar.2007.19.1.71

Dye, R. (2004). Strategy selection and performance measurement choice when profit drivers are uncertain. Management Science, 50(12), 1624-1638. http://dx.doi.org/10.1287/mnsc.1030.0160

Foley, J. (2008). Service delivery reform within the Canadian public sector. Employee Relations, 30(3), $283-303$. http://dx.doi.org/10.1108/01425450810866541

Fornell, C., \& Larcker, D. (1981). Evaluating structural equation models with unobservable variables and measurement error. Journal of Marketing Research, 18(1), 39-50. http://dx.doi.org/10.2307/3151312

Garver, M. S., \& Mentzer, J. T. (1999). Logistics research methods: employing structural equation modeling to test for construct validity. Journal of Business Logistics, 20(1), 33-57.

Gu, F. (2005). Innovation, future earnings, and market efficiency. Journal of Accounting Auditing and Finance, 20(4), 385-418.

Handy, C. R., \& MacDonald, J. M. (1989). Multinational structures and strategies of U.S. food firms. American Journal of Agricultural Economics, 71(5), 1246-1254. http://dx.doi.org/10.2307/1243115

Hoque, Z., \& James, W. (2000). Linking the balanced scorecard measures to size and market factors: Impact on organizational performance. Journal of Management Accounting Research, 12, 1-17. http://dx.doi.org/10.2308/jmar.2000.12.1.1 
Ibrahim, M. E. (1999). Recent Trends to Modernize Performance Evaluation Systems in Economic Enterprises. Administrative Research Review, 11(3), 91-99.

Ittner, C. D., \& Larcker, D. F. (2001). Assessing empirical research in managerial accounting: A value-based management perspective. Journal of Accounting and Economics, 32, 349-410. http://dx.doi.org/10.1016/S0165-4101(01)00026-X

Joreskog, K. G. (1973). Analysis of covariance structures. In P. R. Krishnaiah (Ed), Multivariate Analysis-III (pp. 263-285). New York: Academic Press. http://dx.doi.org/10.1016/B978-0-12-426653-7.50024-7

Kaplan, R. S., \& Norton, D. P. (1992). The balanced scorecard: measures that drive performance. Harvard Business Review, 70(1), 71-79.

Kaplan, R. S., \& Norton, D. P. (1996). Using the balanced scorecard as a strategic management System. Harvard Business Review, 74(1), 75-85.

Kaplan, R. S., \& Norton, D. P. (2001). The strategy focused organization: How balanced scorecard companies thrive in the new business environment. Boston: Harvard Business School Press.

Kline, R. B. (1998). Principles and practice of structural equation modeling. New York: Guilford Press.

Koufteros, X. A., Vonderembse, M. A., \& Doll, W. J. (1998). Developing measures of time-based manufacturing. Journal of Operations Management, 16(1), 21-41. http://dx.doi.org/10.1016/S0272-6963(97)00027-2

Lee, M. C., \& Hwan, I. S. (2005). Relationships among service quality, customer satisfaction and profitability in the Taiwanese banking industry. International Journal of Management, 22(4), 635-648.

Lewis, B. R., Orledge, J., \& Mitchell, V. (1994). Service quality: students' assessment of banks and building societies. International Journal of Bank Marketing, 12(4), 3-12. http://dx.doi.org/10.1108/02652329410057978

Naser, K., Jamal, A., \& Al-Khatib, K. (1999). Islamic banking: a study of customer satisfaction and preferences in Jordan. International Journal of Bank Marketing, 17(3), 135-150. http://dx.doi.org/10.1108/02652329910269275

Oliver, R. L. (1980). A cognitive model of the antecedents and consequences of satisfaction decisions. Journal of Marketing Research, 17(4), 460-469. http://dx.doi.org/10.2307/3150499

Othman, A., \& Owen, L. (2001). Adopting and measuring customer service quality (SQ) in Islamic banking: A case study in Kuwait Finance House. International Journal of Islamic Financial Services, 3(1), 1-26.

Parasuraman, A., Zeithaml, V. A., \& Berry, L. L. (1985). A conceptual model of service quality and its implications for future research. Journal of Marketing, 49(4), 41-50. http://dx.doi.org/10.2307/1251430

Parasuraman, A., Zeithaml, V. A., \& Berry, L. L. (1988). SERVQUAL: A multiple-item scale for measuring consumer perceptions of service quality. Journal of Retailing, 64(4), 12-40.

Parasuraman, A., Zeithaml, V. A., \& Berry, L. L. (1991). Refinement and reassessment of SERVQUAL scale. Journal of Retailing, 67(4), 181-190.

Parasuraman, A., Zeithaml, V. A., \& Berry, L. L. (1994). Reassessment of expectations as a comparison standard in measuring service quality: Implications for further research. Journal of Marketing, 58(1), 111-124. http://dx.doi.org/10.2307/1252255

Porter, M. E. (1992). Capital disadvantage: America's falling capital investment system. Harvard Business Review, 70(5), 65-82.

Raphael, G., \& Man, W. (2013). Integrating Financial and Non-Financial Measures to Measure the performance of Commercial Banks: Evidence from Tanzania. Research Journal of Finance and Accounting, 4(3), 1-11.

Stewart, D. (2009). Marketing accountability: Linking marketing actions to financial results. Journal of Business Research, 62(6), 636-643. http://dx.doi.org/10.1016/j.jbusres.2008.02.005

Teas, R. K. (1993). Consumer expectations and the measurement of perceived service quality. Journal of Professional Services Marketing, 8(2), 33-54. http://dx.doi.org/10.1300/J090v08n02p05

Vanniarajan, T., \& Anbazhagan, B. (2007). SERVPERF analysis in retail banking. Proceedings of the International Marketing Conference on Marketing \& Society, 726-736.

Zhou, L. (2004). A dimension-specific analysis of performance-only measurement of service quality and satisfaction in China's retail banking. Journal of Services Marketing, 18(7), 534-546. 
http://dx.doi.org/10.1108/08876040410561866

\section{Copyrights}

Copyright for this article is retained by the author(s), with first publication rights granted to the journal.

This is an open-access article distributed under the terms and conditions of the Creative Commons Attribution license (http://creativecommons.org/licenses/by/3.0/). 